\title{
The Impact of Family Social Network on Household Consumption
}

\author{
Xi Kang \\ College of Economics, Jinan University, Guangzhou, China \\ Email: mu1781972@126.com
}

How to cite this paper: Kang, X. (2019) The Impact of Family Social Network on Household Consumption. Modern Econo$m y, 10,679-697$.

https://doi.org/10.4236/me.2019.103046

Received: December 25, 2018

Accepted: March 12, 2019

Published: March 15, 2019

Copyright (C 2019 by author(s) and Scientific Research Publishing Inc. This work is licensed under the Creative Commons Attribution International License (CC BY 4.0).

http://creativecommons.org/licenses/by/4.0/

\begin{abstract}
Based on the 2016 China Family Panel Studies (CFPS), this paper investigates the impact of China's family social network on the total consumption level of residents and other three levels: survival consumption, enjoyable consumption and developmental consumption. The research shows: 1) Family social network has a significant effect on the consumption expenditure of residents, especially on the enjoyable consumption expenditure; 2) Social network can promote family consumption by alleviating the restriction of family mobility and demonstration effect; 3 ) The effects of social networks on consumption are different among different types of families. Compared with the eastern families, the social network of central and western families plays a more prominent role in promoting consumption expenditure. Families with lower income level reply heavily social network, and the effect of social network to stimulate consumption is more obvious.
\end{abstract}

\section{Keywords}

Social Network, Household Consumption, Survival Consumption, Enjoyable Consumption, Developmental Consumption

\section{Introduction}

Residents' consumption has always been one of the hotspots of economic development. In the report of the 19th National Congress of the CPC, it is pointed out that we should focus on cultivating new growth points of middle and high-end consumption, improving the system and mechanism of promoting consumption, and strengthening the basic role of consumption in economic development. With the development of economy, the consumption level and mode of residents have also changed. From the perspective of different consumption levels, it can be summarized as the proportion of survival consumption in the total consump- 
tion of residents' declines and changes to the consumption pattern of enjoyment and development, that is, residents' consumption develops towards middle and high-end consumption. In order to explore the influencing factors of consumer behavior changes, many scholars have conducted investigations and studies, but most of the studies are carried out from the perspective of mainstream economics, such as credit market, asset allocation, monetary policy and so on. With the rise of socioeconomics and behavioral economics, the perspective of economic analysis has begun to expand to the interaction and behavior between economic subjects. China is a traditional relationship-based society, which pays more attention to interpersonal relationships. Social networks play an important role in economic and social life. As a special kind of family capital, social network of family also arouses attention and research on its influence on residents' consumption behavior. On the one hand, consumption can not only bring people material enjoyment, but also enhance the exchange and transmission of information. For families with a wider social network, it also carries social significance and status attributes. Therefore, social networks can make consumption decisions for families through the communication and demonstration effects produced by residents in the process of social interaction. It will affect the consumption level and consumption structure of residents. On the other hand, social networks can give people such as job opportunities, financing channels and access to information to help, as an informal system to provide security for families, reduce the sensitivity of families to risk, and risk attitudes are important factors affecting household consumption decisions, so families can share risk through social networks, so as to mitigate the inhibitory effect of risk on Residents' consumption. This shows that the impact of social networks on consumption worthy of more in-depth study.

The rest of the article is structured as follows. The second part combs the domestic and foreign literature about social network and resident consumption; the third part empirically analyzes the impact of family social network on different levels of consumer level and its impact mechanism; the fourth part is the robustness test; the fifth part is the conclusion.

\section{Literature Review}

Social network is a broader concept that covers sociology, economics and psychology. As a social capital, a non-market and informal institutional force, social network plays a special role in family and society, and has attracted more and more scholars' attention. Scholars at home and abroad have done a lot of research on it. Research has yet to form a unified definition. Mitchell (1969) [1] explores social networks from the perspective of social relations, and holds that social networks are direct or indirect social relationships that are linked to each other through material and cultural environments. Granovetter (1973) [2] found that social networks play an important role in the transmission and communication of information. Putnam (1993) [3] found that social networks can reduce transaction costs, because the more developed the family's social network, the 
stronger trust between groups can be established, reducing moral hazards and other issues. Bloch (2008) [4] pointed out that social network can bring risk sharing network to families, and family members share risk through the role of social network transfer payment and information transmission. Shuang Zhang (2007) [5] believes that social networks have the functions of acquiring resources, sharing information, sharing risks, smoothing consumption, reducing opportunistic behavior and improving collective decision-making. Ming Lu (2008) [6] pointed out that social networks, as an informal system, play an important role in helping each other, sharing risks and information among members. Tao Li (2009) [7] Based on the survey data of investment behavior of urban residents in China, it is found that social interaction helps to alleviate the degree of subjective perception of uncertainty such as risk. Yunnan Guo (2015) [8] believes that social networks play an important role in the allocation of resources and the formation of informal systems because of the role of information sharing, guaranteeing or risk sharing, which can make up for the shortcomings of formal systems.

As a kind of social capital owned by family, social network plays an important role in information sharing and risk sharing. Like the material capital and human capital owned by family, social network can affect family decision-making and consumption behavior. Angelucci (2010) [9] proposed the risk sharing mechanism of social network, found that family members can share the risk through the role of social network information sharing, thus helping families smooth consumption; Yong Ma and Yongxiu Bai (2009) [10] Research results show that farmers' families can share the risk through social networks, and the more developed the social network, the more smoothly the consumption will be when they encounter income risks. Yunnan Guo (2012) [11] analyzes the impact of clan network on household smooth consumption in Chinese villages, and finds that the existence of clan network or the increase of its intensity provide more complete smooth consumption for rural households. Yu Hu (2013) [12] holds that the acquisition of consumer information by individuals will be circulated and disseminated through social networks, and the "relationship-based" characteristics of Chinese society will make the formation of individual consumer preferences inevitably affected by the individual social network embedded in consumer behavior. Hui Zhong, Liyuan Deng (2015) [13] based on the analysis of China's household finance micro-survey data, it is found that social network can alleviate the inhibition of increasing risk aversion on household consumption, and is more prominent in durable goods consumption. Xiaodan $\mathrm{Wu}$ and Junwen Li (2015) [14] introduced liquidity constraints and social networks into the household consumption model. Social networks can alleviate the inhibiting effect of liquidity constraints on household consumption to a certain extent. Bin Hang (2015) [15] used micro-data Empirical to analyze the relationship between human expenditure and consumption of urban households, the result shows that human expenditure has a greater effect on consumption than crowding-out effect. Yongqing Nan and Qin Zhou (2018) [16] used the quantile re- 
gression method to investigate the effect of social network on consumption level in different distribution of consumption conditions.

At present, there is little empirical research on the impact of social network on consumption at different levels and its mechanism. This paper will introduce the consumption level into the research framework from the micro perspective, and use micro-household data to empirically study the impact of family social network on consumption level and consumption structure and its communication. The mechanism of smoothing consumption is through risk sharing. This study will help to understand the impact of family social network on household consumption, provide a new perspective for the study of household consumption behavior, and provide preliminary empirical evidence for promoting household consumption in China.

\section{Empirical Analysis}

\subsection{Data Sources and Variable Descriptions}

The data used in this empirical study are from the latest China Family Panel Studies (CFPS) published on the official website of the Chinese Social Science Research Center of Peking University in 2016. CFPS is a biennial large-scale micro-household follow-up survey. There are four main types of questionnaires: community questionnaires, family questionnaires, adult questionnaires and children's questionnaires. The sample covers about 16,000 households in 31 provinces/municipalities/autonomous regions except Hong Kong, Macao and Taiwan. It is a national, large-scale and multidisciplinary social follow-up survey project. The data used in this paper are from CFPS Adult Questionnaire and Family Questionnaire in 2016. Since there is no information about the head of household in the questionnaire, this paper identifies the head of household according to the "financial respondent" and matches the sample of family and adult with "personal ID". Because the urban household consumption content is more abundant, the level of consumption is more complete and more representative, the rural household data are excluded, and only the urban household data are retained, and the missing and abnormal values of variables are excluded. Finally, 5719 observation values are obtained.

The explanatory variable of this empirical study is household consumption expenditure. Choose the annual per capita consumption expenditure as a dependent variable to analyze the impact of social network on the consumption level of residents, and divide the consumption expenditure into three levels: survival consumption, enjoyable consumption and developmental consumption to analyze the impact of family social network on the consumption structure of residents. The core explanatory variable is social network. According to the previous research literature, the selected indicators are mainly as follows: Ming $\mathrm{Lu}$ (2009) [6], Rudai Yang (2011) [17], Guangrong Ma (2011) [18] selected the family's personal gift expenditure as the proxy variable of social network. The family's personal gift expenditure can maintain the social network between relatives 
and friends. The more the personal gift expenditure, the larger the family's social network scale is. Yanjie Bian (2004) [19], Feng Hu (2012) [20] selected the number of visits by relatives and friends during the Spring Festival as the proxy variable of social network. The number of visits directly reflects the family's interpersonal communication. The more the number, the wider the social network. Zhao Chen (2009) [21] used "the number of relatives and friends who help in job hunting" as a measure of social network. Considering the above indicators, the "human relationship gift expenditure" is a relatively appropriate and easily accessible measurement index, and has been supported by many relevant literature studies. Therefore, this paper will select the family relationship gift expenditure as the proxy variable of social network.

This paper also controls the variables of individual and family characteristics, including family size, family net income, family net assets, family housing net assets, urban and rural classification, gender, age, educational background, marital status, health status, work status. The definition and descriptive statistics of all variables are shown in Table 1.

\subsection{Model Setting}

This paper uses the following model to study the impact of family social network on the consumption level of residents, and divides consumption expenditure into survival consumption expenditure, enjoyment consumption expenditure and development consumption expenditure.

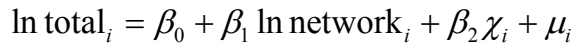

$$
\begin{aligned}
& \text { ln survive }{ }_{i}=\beta_{0}+\beta_{1} \ln \text { network }_{i}+\beta_{2} \chi_{i}+\mu_{i} \\
& \ln \text { enjoy }_{i}=\beta_{0}+\beta_{1} \text { ln network }_{i}+\beta_{2} \chi_{i}+\mu_{i} \\
& \ln \text { develop }_{i}=\beta_{0}+\beta_{1} \ln \text { network }_{i}+\beta_{2} \chi_{i}+\mu_{i}
\end{aligned}
$$

In Equation (1), $\ln$ total $_{i}$ represents the logarithm of the total consumption expenditure of family I in the whole year. In Equation (2), $\ln$ survive $_{i}$ represents the logarithm of the survival consumption expenditure of family I in the whole year. In Equation (3), ln enjoy ${ }_{i}$ represents the logarithm of enjoyment consumption expenditure of family I in the whole year. In Equation (4), ln develop represents the logarithm of development consumption expenditure of family I in the whole year. In network ${ }_{i}$ represents the social network of family I and take the household average human relationship and gift expenditure as the proxy variable. $\chi_{i}$ is a personal characteristic variable and a family characteristic variable. $\mu_{i}$ is a random disturbance term.

\subsection{Empirical Results and Analysis}

The mixed OLS regression method is used to estimate the above models, and the regression results are as follows (Table 2).

From the above regression results, we can see that the elasticity coefficient of social network to the total consumption level is 0.0462 , that is, the total 
Table 1. Variable definition and descriptive statistics.

\begin{tabular}{|c|c|c|c|c|c|}
\hline $\begin{array}{l}\text { Variable } \\
\text { identifier }\end{array}$ & Variable description & $\begin{array}{l}\text { Mean } \\
\text { value }\end{array}$ & $\begin{array}{l}\text { Standard } \\
\text { deviation }\end{array}$ & $\begin{array}{l}\text { Minimum } \\
\text { value }\end{array}$ & $\begin{array}{l}\text { Maximum } \\
\text { value }\end{array}$ \\
\hline lntotal & $\begin{array}{l}\text { The logarithm of total } \\
\text { consumption expenditure }\end{array}$ & 10.821 & 0.805 & 8.380 & 12.913 \\
\hline lnsurvive & $\begin{array}{l}\text { The logarithm of the sum of food, } \\
\text { housing and clothing expenditures }\end{array}$ & 10.292 & 0.814 & 7.618 & 12.282 \\
\hline lnenjoy & $\begin{array}{l}\text { The logarithm of the sum of } \\
\text { expenditure on household } \\
\text { equipment and daily necessities and } \\
\text { transportation and communications }\end{array}$ & 8.831 & 1.212 & 5.480 & 12.427 \\
\hline lndevelop & $\begin{array}{l}\text { The logarithm of the sum of } \\
\text { expenditure on culture, entertainment, } \\
\text { education and health care }\end{array}$ & 8.510 & 1.320 & 4.605 & 11.082 \\
\hline lnnetwork & $\begin{array}{l}\text { The logarithm of } \\
\text { human gift expenditure }\end{array}$ & 7.139 & 2.666 & 0 & 10.308 \\
\hline lnincome & $\begin{array}{c}\text { The logarithm of net income } \\
\text { of households }\end{array}$ & 10.525 & 1.892 & 0 & 12.899 \\
\hline lnfinanceasset & $\begin{array}{l}\text { The logarithm of financial } \\
\text { assets of households }\end{array}$ & 7.282 & 4.933 & 0 & 13.815 \\
\hline Size & Number of household population & 3.525 & 1.733 & 1 & 14 \\
\hline Gender & Male $=1$, female $=0$ & 0.463 & 0.498 & 0 & 1 \\
\hline Age & Age of head of household & 49.308 & 15.170 & 18 & 95 \\
\hline Edu & $\begin{array}{c}\text { Illiteracy/semi-illiteracy }=1, \\
\text { primary school }=2, \\
\text { junior high school }=3, \\
\text { senior high school/technical } \\
\text { school } / \text { vocational high school }=4, \\
\text { junior college }=5, \text { undergraduate }=6, \\
\text { master's degree and above }=7\end{array}$ & 3.048 & 1.425 & 1 & 7 \\
\hline Marriage & Unmarried $=0$, married $=1$ & 0.941 & 0.234 & 0 & 1 \\
\hline Health & $\begin{array}{l}\text { Very unhealthy }=1, \text { unhealthy }=2 \text {, } \\
\text { relatively unhealthy }=3, \\
\text { generally }=4 \text {, health }=5\end{array}$ & 2.852 & 1.145 & 1 & 5 \\
\hline Work status & $\begin{array}{l}\text { Unemployment or unemployment }=0 \text {, } \\
\text { employment }=1\end{array}$ & 0.652 & 0.476 & 0 & 1 \\
\hline
\end{tabular}

Data source: China family panel studies from 2016.

consumption level increases by $4.62 \%$ with the increase of $1 \%$ of the family expenditure on maintaining and expanding the social network, which indicates that the family social network can significantly improve the overall consumption level of residents.

This paper will further divide the eight types of consumption expenditure into three levels: survival consumption, enjoyable consumption and development consumption, and further explore the impact of social network on different levels of consumption. 
Table 2. The return results of the impact of family social network on residents' consumption.

\begin{tabular}{|c|c|c|c|c|}
\hline & $\begin{array}{c}(1) \\
\text { lntotal }\end{array}$ & $\begin{array}{c}(2) \\
\text { lnsurvive }\end{array}$ & $\begin{array}{c}(3) \\
\text { lnenjoy }\end{array}$ & $\begin{array}{c}(4) \\
\text { lndevelop }\end{array}$ \\
\hline lnnetwork & $\begin{array}{c}0.046^{* * *} \\
(0.009)\end{array}$ & $\begin{array}{c}0.039^{* * *} \\
(0.008)\end{array}$ & $\begin{array}{c}0.071^{* * *} \\
(0.008)\end{array}$ & $\begin{array}{c}0.041^{* * *} \\
(0.010)\end{array}$ \\
\hline lnincome & $\begin{array}{c}0.062^{\star * *} \\
(0.012)\end{array}$ & $\begin{array}{c}0.065^{\star * \star} \\
(0.013)\end{array}$ & $\begin{array}{c}0.084^{\star \star \star} \\
(0.010)\end{array}$ & $\begin{array}{c}0.052^{\star * *} \\
(0.016)\end{array}$ \\
\hline lnfinanceasset & $\begin{array}{c}0.008^{\star * *} \\
(0.002)\end{array}$ & $\begin{array}{c}0.013^{\star * *} \\
(0.002)\end{array}$ & $\begin{array}{c}0.016^{\star * *} \\
(0.002)\end{array}$ & $\begin{array}{l}-0.004 \\
(0.003)\end{array}$ \\
\hline Size & $\begin{array}{c}0.106^{\star * *} \\
(0.006)\end{array}$ & $\begin{array}{c}0.079^{* * *} \\
(0.005)\end{array}$ & $\begin{array}{c}0.140^{* * *} \\
(0.013)\end{array}$ & $\begin{array}{c}0.205^{\star * *} \\
(0.013)\end{array}$ \\
\hline Gender & $\begin{array}{c}0.010 \\
(0.032)\end{array}$ & $\begin{array}{c}0.026 \\
(0.025)\end{array}$ & $\begin{array}{l}-0.002 \\
(0.040)\end{array}$ & $\begin{array}{c}-0.108^{\star * *} \\
(0.038)\end{array}$ \\
\hline Age & $\begin{array}{c}-0.010^{*} \\
(0.004)\end{array}$ & $\begin{array}{l}-0.007 \\
(0.006)\end{array}$ & $\begin{array}{l}-0.004 \\
(0.006)\end{array}$ & $\begin{array}{l}-0.003 \\
(0.010)\end{array}$ \\
\hline Edu & $\begin{array}{c}0.143^{* * *} \\
(0.011)\end{array}$ & $\begin{array}{c}0.142^{* * *} \\
(0.013)\end{array}$ & $\begin{array}{c}0.171^{* * *} \\
(0.010)\end{array}$ & $\begin{array}{c}0.138^{* * *} \\
(0.014)\end{array}$ \\
\hline Marriage & $\begin{array}{c}0.223^{* * *} \\
(0.054)\end{array}$ & $\begin{array}{l}0.148^{\star *} \\
(0.058)\end{array}$ & $\begin{array}{c}0.254^{* * *} \\
(0.057)\end{array}$ & $\begin{array}{c}0.536^{\star * *} \\
(0.109)\end{array}$ \\
\hline Health & $\begin{array}{l}-0.009 \\
(0.008)\end{array}$ & $\begin{array}{l}0.025^{\star *} \\
(0.010)\end{array}$ & $\begin{array}{c}0.010 \\
(0.007)\end{array}$ & $\begin{array}{c}-0.143^{\star * *} \\
(0.019)\end{array}$ \\
\hline Work status & $\begin{array}{c}-0.097^{* * *} \\
(0.020)\end{array}$ & $\begin{array}{c}-0.178^{* * *} \\
(0.022)\end{array}$ & $\begin{array}{c}0.051 \\
(0.034)\end{array}$ & $\begin{array}{l}-0.031 \\
(0.043)\end{array}$ \\
\hline Provincial fixed effect & YES & YES & YES & YES \\
\hline Constant term & $\begin{array}{c}9.585 \\
(0.186)\end{array}$ & $\begin{array}{c}9.227 \\
(0.195)\end{array}$ & $\begin{array}{c}6.825 \\
(0.196)\end{array}$ & $\begin{array}{c}6.852 \\
(0.376)\end{array}$ \\
\hline adj R-squared & 0.303 & 0.309 & 0.328 & 0.155 \\
\hline Sample size & 5298 & 5280 & 5302 & 5242 \\
\hline
\end{tabular}

Note: The values in parentheses are robust standard errors. ${ }^{*},{ }^{* *},{ }^{* *}$ indicate significant levels at the $10 \%$, $5 \%$, and $1 \%$ significance levels, respectively, and () is the t-statistic value.

\subsubsection{The Impact of Social Network on the Survival Consumption}

The coefficient of influence of social network on living consumption is 0.0399 , which is smaller than that of other kinds of consumption. This shows that the influence of social network on living consumption is weaker. The living consumption consists of food consumption, clothing consumption and residential consumption. It is the basic consumption to meet the necessities of physiological needs, so the impact of social networks is relatively small. With the increase of residents' income and living standards, the proportion of living consumption is gradually decreasing, while the proportion of enjoying and developing consumption is increasing, which indicates that the consumption structure of residents is in the process of adjustment and optimization and upgrading.

\subsubsection{The Influence of Social Network on Enjoyable Consumption}

The elasticity coefficient of social network to enjoyable consumption is 0.0712 , 
which is significantly higher than that of other types of consumption. This shows that social network has the greatest effect on the promotion of enjoyable consumption. With the development of economy and society and the improvement of people's living standards, the residents are pursuing higher level of consumption, such as comfort and enjoyment, so they are more inclined to enjoy consumption, which mainly includes household equipment and daily necessities expenditure and transportation and communication expenditure. On the one hand, the larger the scale of social network and the more frequent the interpersonal communication, the more traffic and communication expenditure in enjoyable consumption. On the other hand, the circulation and dissemination of consumption information in social network will greatly affect the consumption preferences of family members, which can be reflected through demonstration effect and comparison effect in the process of interpersonal communication. The consumption behavior of the members of social network can be heard and stimulate consumption, especially for the visible consumption such as household equipment and daily necessities expenditure in enjoyable consumption, which can better show the consumption ability of the members, and then stimulate the consumption desire of the family.

\subsubsection{The Influence of Social Network on Developmental Consumption}

The influence coefficient of social network on developmental consumption is 0.0410 , which is only next to enjoyable consumption. This indicates that social network plays a significant role in promoting developmental consumption. $\mathrm{Hu}$ man capital is the core factor to construct the family social network. In order to satisfy their own better development and cultivate the family human capital, the family's consumption demand for health and education will be greater. The development-oriented consumption includes medical and health care consumption and cultural and educational entertainment consumption, so the larger the scale of family social networks, the greater the demand for developmental consumption.

To sum up, social network can improve the overall consumption level of families, especially for the enjoyment consumption and development consumption. Therefore, social network can help release the consumption potential of residents and promote the adjustment and upgrading of residents' consumption structure.

\subsubsection{The Influence of Other Control Variables on Residents' Consumption Level}

From the perspective of the impact of family characteristics on consumption, the influence coefficients of household income on total consumption and various types of consumption are $0.0628,0.0653,0.0840$ and 0.0524 , respectively, which are significant at the level of $1 \%$ and larger than that of social network, indicating that household income is the main factor affecting current consumption. Family financial assets have a positive effect on residents' consumption in general, but the influence coefficient is smaller than that of social network and fami- 
ly's total annual income. This shows that the more family financial assets are, the more wealth they have, the more consumption expenditure they will have. But families will plan the consumption level of each period according to their own wealth level, so the level of family financial assets has a positive effect on current consumption. The impact factor on development consumption is negative but not significant, which indicates that household financial assets may bring crowding-out effect as well as wealth effect. Families allocate more assets to financial assets, thus reducing investment in development consumption. The influence coefficient of household population size on household consumption is significantly positive, that is, the more the household population, the more the household consumption expenditure.

From the perspective of the impact of personal characteristics on household consumption, the gender, age and health status of the head of household have no significant impact on consumption, because the level of household consumption is determined by all family members, and these indicators of the head of household cannot represent the situation of the whole family, so the impact of household consumption is not significant, while the head of household's educational background and marital status have significant impact on various consumption coefficients. In general, the higher the educational level of the head of the household, the higher the educational level of the family members, the stronger the overall strength of the family and the higher the consumption level.

\subsection{Instrumental Variable Estimation}

In this paper, according to the practice of previous literature and considering the availability of data, we choose the human gift expenditure as the proxy variable of social network. On the one hand, there may be consumption expenditure in the form of festival gifts. To a certain extent, social network needs consumption expenditure to maintain and expand. On the other hand, human gift expenditure and consumption expenditure are also affected by many variables, such as family background, consumption habits, personality characteristics and so on. Therefore, in the process of the regression of social network and consumption expenditure, which takes the human relationship gift expenditure as the proxy variable, there are problems of reverse causality and missing variables, which will lead to serious endogenous problems.

Referring to the existing literature, we generally consider the social characteristics and data availability to select the appropriate tool variables, such as Lin Jianhao (2018) [22] believe that families with ancestral temples or genealogy will participate in more collective ceremonies and activities, which will contribute to the maintenance and expansion of family social network, and choose whether families build ancestral temples or have genealogy as the tool variables of social network. Ma Guangrong (2011) [18] considers that Chinese farmers are deeply influenced by consanguinity and clan relationship, and chooses "is it the first surname in the village" as the tool variable of farmers' social network. Zhang Yuan (2009) [23] chose "family component" before reform and opening-up as 
the tool variable of social network. Referring to the practice of Yang Rudai (2011) [17], this paper uses the per capita social gift expenditure of community households as a tool variable of the per capita family gift expenditure, because the expenditure of community human gift reflects the social customs of the region to a certain extent, and can affect the level of family human gift expenditure, but it has no relationship with the consumption of individual families, so the per capita social gift expenditure of community households is not related. Therefore, the expenditure of per capita social gift of community households meets the two conditions of correlation and Exogenousness of instrumental variables, and the use of per capita social gift expenditure of community households can also reduce the possibility of measurement errors, which is a good proxy variable. This paper classifies and calculates the urban households in different provinces according to the "district-county sequence code" in the database, and obtains the average gift expenditure variables of the community in which the households belong. Then, it uses 2SLS model to re-estimate the impact of social network on household consumption. The regression results are shown in Table 3.

Table 3. Influence of social network on household consumption: 2SLS model.

\begin{tabular}{|c|c|c|c|c|}
\hline & $\begin{array}{c}(1) \\
\text { lntotal }\end{array}$ & $\begin{array}{c}(2) \\
\text { lnsurvive }\end{array}$ & $\begin{array}{c}(3) \\
\text { lnenjoy }\end{array}$ & $\begin{array}{c}(4) \\
\text { lndevelop }\end{array}$ \\
\hline lnnetwork & $\begin{array}{c}0.046^{* * *} \\
(0.009)\end{array}$ & $\begin{array}{c}0.039^{* * *} \\
(0.008)\end{array}$ & $\begin{array}{c}0.071^{* * *} \\
(0.008)\end{array}$ & $\begin{array}{c}0.041^{* * *} \\
(0.010)\end{array}$ \\
\hline lnincome & $\begin{array}{c}0.062^{\star * *} \\
(0.012)\end{array}$ & $\begin{array}{c}0.065^{\star * *} \\
(0.013)\end{array}$ & $\begin{array}{c}0.084^{* * *} \\
(0.010)\end{array}$ & $\begin{array}{c}0.052^{\star * *} \\
(0.016)\end{array}$ \\
\hline lnfinanceasset & $\begin{array}{c}0.008^{* * *} \\
(0.002)\end{array}$ & $\begin{array}{c}0.013^{* * *} \\
(0.002)\end{array}$ & $\begin{array}{c}0.016^{* * *} \\
(0.002)\end{array}$ & $\begin{array}{l}-0.004 \\
(0.003)\end{array}$ \\
\hline Size & $\begin{array}{c}0.106^{* * *} \\
(0.006)\end{array}$ & $\begin{array}{c}0.079^{* * *} \\
(0.005)\end{array}$ & $\begin{array}{c}0.140^{* * *} \\
(0.013)\end{array}$ & $\begin{array}{c}0.205^{* * *} \\
(0.013)\end{array}$ \\
\hline Gender & $\begin{array}{c}0.010 \\
(0.032)\end{array}$ & $\begin{array}{c}0.026 \\
(0.025)\end{array}$ & $\begin{array}{l}-0.002 \\
(0.040)\end{array}$ & $\begin{array}{c}-0.108^{* * *} \\
(0.038)\end{array}$ \\
\hline Age & $\begin{array}{c}-0.010^{*} \\
(0.004)\end{array}$ & $\begin{array}{l}-0.007 \\
(0.006)\end{array}$ & $\begin{array}{l}-0.004 \\
(0.006)\end{array}$ & $\begin{array}{l}-0.003 \\
(0.010)\end{array}$ \\
\hline Edu & $\begin{array}{c}0.143^{* * *} \\
(0.011)\end{array}$ & $\begin{array}{c}0.142^{* * *} \\
(0.013)\end{array}$ & $\begin{array}{c}0.171^{* * *} \\
(0.010)\end{array}$ & $\begin{array}{c}0.138^{* * *} \\
(0.014)\end{array}$ \\
\hline Marriage & $\begin{array}{c}0.223^{* * *} \\
(0.054)\end{array}$ & $\begin{array}{l}0.148^{* *} \\
(0.058)\end{array}$ & $\begin{array}{c}0.254^{* * *} \\
(0.057)\end{array}$ & $\begin{array}{c}0.536^{* * *} \\
(0.109)\end{array}$ \\
\hline Health & $\begin{array}{l}-0.009 \\
(0.008)\end{array}$ & $\begin{array}{l}0.025^{\star *} \\
(0.010)\end{array}$ & $\begin{array}{c}0.010 \\
(0.007)\end{array}$ & $\begin{array}{c}-0.143^{* * *} \\
(0.019)\end{array}$ \\
\hline Work status & $\begin{array}{c}-0.097^{\star * *} \\
(0.020)\end{array}$ & $\begin{array}{c}-0.178^{\star \star \star} \\
(0.022)\end{array}$ & $\begin{array}{c}0.051 \\
(0.034)\end{array}$ & $\begin{array}{l}-0.031 \\
(0.043)\end{array}$ \\
\hline Provincial fixed effect & YES & YES & YES & YES \\
\hline Constant term & $\begin{array}{c}9.585 \\
(0.186)\end{array}$ & $\begin{array}{c}9.227 \\
(0.195)\end{array}$ & $\begin{array}{c}6.825 \\
(0.196)\end{array}$ & $\begin{array}{c}6.852 \\
(0.376)\end{array}$ \\
\hline adj R-squared & 0.303 & 0.309 & 0.328 & 0.155 \\
\hline One-stage $\mathrm{F}$ value & 311.547 & 350.136 & 321.217 & 344.39 \\
\hline Sample size & 5298 & 5280 & 5302 & 5242 \\
\hline
\end{tabular}

Note: The values in parentheses are robust standard errors. ${ }^{*},{ }^{* *},{ }^{* *}$ indicate significant levels at the $10 \%$, $5 \%$, and $1 \%$ significance levels, respectively, and () is the t-statistic value. 
From the results of two-stage regression, we can see that the influence coefficients of using the per capita human gift expenditure of community households as the tool variable of social network on the total household consumption, survival consumption, enjoyment consumption and development consumption are $0.0974,0.0904,0.1254$ and 0.0965 respectively, and are significant at the level of $1 \%$. The influence on survival consumption is the smallest, followed by that on development consumption. Enjoyment consumption has the greatest impact. The results of 2SLS regression are generally consistent with those of OLS regression, but the values of 2SLS regression coefficients are higher than those of OLS regression coefficients, which indicates that OLS may underestimate the positive effect of social network on household consumption. Staiger \& Stock (1997) [24] proposed in the rule of thumb that when there is only one endogenous variable, if the F-test value of one-stage regression is greater than 10, there will be no problem of weak instrumental variables. The F-test values in the regression results are $311.547,350.136,321.217$ and 344.39 , which are significantly greater than 10, which excludes the possibility of weak instrumental variables. In conclusion, after considering the endogenous problem of social network, the positive effect of social network on household consumption is still significant.

\subsection{The Influence Mechanism of Social Network on Family Consumption}

From the above analysis, we can see that the family social network has a significant positive impact on residents' consumption, especially on the promotion of enjoyable consumption. This part will discuss and analyze the mechanism of the impact of social network on consumption.

Members of social networks can understand other members' information through interaction, and it is easy to find reference groups through social networks. Yu Hu (2013) [12] pointed out that the acquisition of consumer information by individuals is largely circulated and disseminated through the network around them. The formation of individual consumption preferences will inevitably be influenced by the network of individual social relations embedded in consumer behavior. Therefore, on the one hand, social networks can stimulate members' consumption through "demonstration effect" and "comparison effect", on the other hand, they can reduce members' subjective perception of uncertainty, that is to say, their sensitivity to risk will decrease, thus making family members' psychological expectations more optimistic and their motivation for Preventive Savings weakened. Alleviate the constraint function of consumption and promote consumption. Bloch (2008) [4] found that transfer payment and information sharing can be carried out among members of the social network, and pointed out that social network can be regarded as a risk-sharing network; Xingjian Yi (2012) [25] believed that family social network as an informal system played a role in reducing income and expenditure uncertainty and alleviating flow. Guangsu Zhou and Guangrong Ma (2015) [26] put forward that the specific mechanism of social network for residents' consumption is mainly reflected 
in reducing income uncertainty and providing informal financing channels. Relatives and friends help each other and share risks with each other. This paper combs the influence path of social network on household consumption, and establishes an empirical model to test the risk sharing mechanism of social network. The following are the path map and empirical model (Figure 1).

This paper will further test the impact mechanism of social network on household consumption through empirical analysis, using intermediary effect model and introducing intermediary variables to test the risk sharing mechanism and demonstration flaunting mechanism of social network respectively. In the risk-sharing mechanism of social networks, social networks play a more direct role through informal financial channels such as lending between relatives and friends and private lending. Therefore, the sum of relatives and friends' borrowing and private borrowing is chosen as the intermediary variable. In the demonstration mechanism of social network, social status is the main psychosocial factor that social network affects consumption. Therefore, the judgment of residents' social status from low to high in the questionnaire survey is chosen as the intermediary variable. From the previous empirical part, we can see that social network has the most significant impact on enjoyable consumption, so the intermediary effect of social network on enjoyable consumption is more obvious, which is conducive to the analysis of the impact mechanism of social network. Therefore, this part mainly investigates the impact mechanism of social network on residents' enjoyable consumption. Table 4 is the definition and descriptive statistics of selected intermediary variables.

This paper uses the hierarchical regression analysis method proposed by Wen Zhonglin and Ye Baojuan (2014) [27] to test the mediation effect. Firstly, the following empirical models are established:

Firstly, the regression model of independent variable social network to dependent variable enjoyable consumption is established. The model is as follows:

$$
\ln _{\text {enjoy }}=\beta_{0}+\beta_{1} \ln \text { network }_{i}+\beta_{2} \chi_{i}+\mu_{i}
$$

Secondly, the regression models of independent variable social network to intermediary variable informal finance and social status are established respectively. The models are as follows:

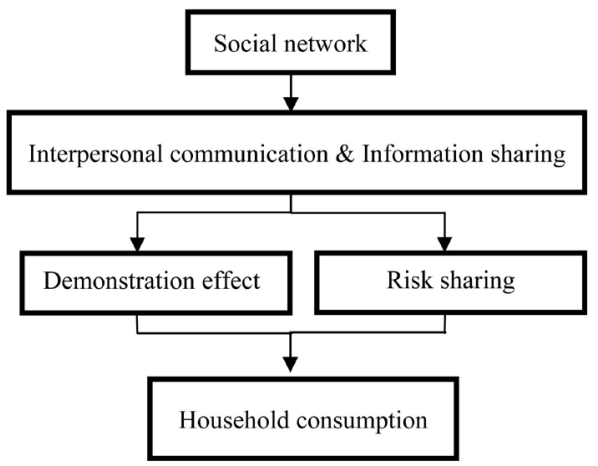

Figure 1. The path map of social network affecting family consumption. 
Table 4. Definition of intermediate variables and descriptive statistics.

\begin{tabular}{cccccc}
\hline $\begin{array}{c}\text { Variable } \\
\text { identifier }\end{array}$ & Variable description & $\begin{array}{c}\text { mean } \\
\text { value }\end{array}$ & $\begin{array}{c}\text { standard } \\
\text { deviation }\end{array}$ & $\begin{array}{c}\text { minimum } \\
\text { value }\end{array}$ & $\begin{array}{c}\text { Maximum } \\
\text { value }\end{array}$ \\
\hline lninfina & $\begin{array}{c}\text { The logarithm of total loan } \\
\text { amount between relatives and } \\
\text { friends and private loans }\end{array}$ & 1.070 & 3.171 & 0 & 14.508 \\
Social status & $\begin{array}{c}\text { Very Low }=1 \text {, very low }=2, \\
\text { generally }=3, \text { very high }=4, \\
\text { very high }=5\end{array}$ & 2.734 & 1.043 & 1 & 5 \\
\hline
\end{tabular}

Data source: China family panel studies from 2016.

$$
\begin{gathered}
\ln _{\text {infina }_{i}}=\alpha_{0}+\alpha_{1} \ln \text { network }_{i}+\alpha_{2} \chi_{i}+\mu_{i} \\
\text { status }_{i}=\alpha_{0}+\alpha_{1} \ln \text { network }_{i}+\alpha_{2} \chi_{i}+\mu_{i}
\end{gathered}
$$

Finally, the regression model of independent variable social network, intermediary variable informal finance and social status on dependent variable enjoyable consumption is established. The model is as follows:

$$
\begin{gathered}
\ln \text { enjoy }_{i}=\gamma_{0}+\gamma_{1} \ln \text { network }_{i}+\gamma_{2} \ln \text { infina }_{i}+\gamma_{3} \chi_{i}+\mu_{i} \\
\ln \text { enjoy }_{i}=\gamma_{0}+\gamma_{1} \ln _{\text {network }}+\gamma_{2} \text { status }_{i}+\gamma_{3} \chi_{i}+\mu_{i}
\end{gathered}
$$

Among them, ln enjoy ${ }_{i}$ represents the logarithm of per capita enjoyable consumption expenditure of household I in the whole year, which is the dependent variable of the test of intermediary effect. In network ${ }_{i}$ denotes the social network of family $i$, and uses the logarithm of per capita personal gift expenditure as the proxy variable, which is the independent variable of the mediation effect test. In infina ${ }_{i}$ denotes the logarithm of the total amount of family I's relatives, friends and private loans, and A denotes the social status of family I's head of household, both of which are mediating variables. status ${ }_{i}$ is a control variable including personal and family characteristics, and $\chi_{i}$ is a stochastic perturbation term.

The coefficient $\beta_{1}$ in Equation (5) is the total effect of the independent variable on the dependent variable. The coefficient $\alpha_{1}$ in Equations (6) and (7) is the effect of the independent variable on the intermediate variable; The coefficient $\gamma_{1}$ in Equations (8) and (9) is the direct effect of the independent variable on the dependent variable after controlling the influence of the intermediate variable. The coefficient $\gamma_{2}$ is the effect of the intermediate variable on the dependent variable after controlling the influence of the independent variable.

The first step in the test of the mediating effect is to test whether the coefficient $\mathrm{A}$ in Equation (5) is significant, and it is significant that the second step is continued. If not, the test is stopped. In the second step, if the coefficient $\alpha_{1}$ in Equation (6) and Equation (7) is significant, the next step is tested. The third step is that if the coefficients $\gamma_{1}$ and $\gamma_{2}$ of Equations (8) and (9) are significantly positive, and the coefficient $\gamma_{1}$ is smaller than the coefficient $\beta_{1}$ of Equation (5), there is a partial mediating effect. If the coefficient $\gamma_{1}$ is not significant and the coefficient $\gamma_{2}$ is significant, It indicates that there is a complete 
mediating effect. The schematic diagram of the mediation effect is shown in Figure 2 .

In this paper, Stata 14 software is used to regression the above models. The results of mediating effect regression are shown in Table 5.

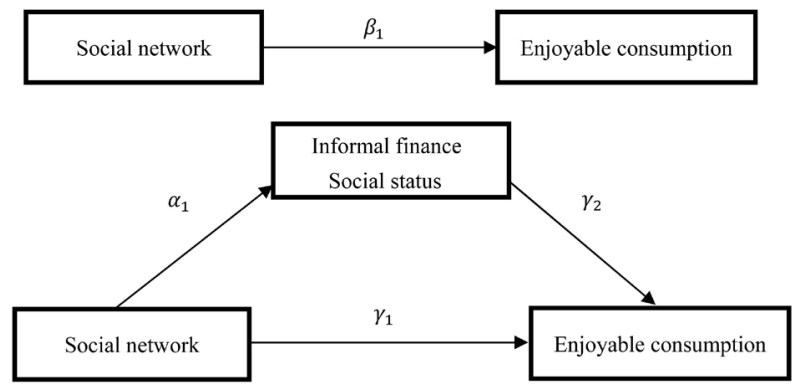

Figure 2. The schematic diagram of mediation effect test.

Table 5. Mediation effect test results.

\begin{tabular}{|c|c|c|c|c|c|}
\hline & $\begin{array}{c}(1) \\
\text { lnenjoy }\end{array}$ & $\begin{array}{c}(2) \\
\text { lninfina }\end{array}$ & $\begin{array}{c}(3) \\
\text { lnenjoy }\end{array}$ & $\begin{array}{c}(4) \\
\text { lnenjoy }\end{array}$ & $\begin{array}{c}(5) \\
\text { lnenjoy }\end{array}$ \\
\hline lnnetwork & $\begin{array}{c}0.071^{* * *} \\
(0.008)\end{array}$ & $\begin{array}{c}0.033^{*} \\
(0.0198)\end{array}$ & $\begin{array}{l}0.019^{* *} \\
(0.008)\end{array}$ & $\begin{array}{c}0.070^{* * *} \\
(0.008)\end{array}$ & $\begin{array}{c}0.071^{* * *} \\
(0.008)\end{array}$ \\
\hline lninfina & - & - & - & $\begin{array}{l}0.010^{* *} \\
(0.004)\end{array}$ & - \\
\hline Social status & - & - & - & - & $\begin{array}{c}0.043^{* * *} \\
(0.013)\end{array}$ \\
\hline lnincome & $\begin{array}{c}0.084^{* * *} \\
(0.010)\end{array}$ & $\begin{array}{l}-0.022 \\
(0.027)\end{array}$ & $\begin{array}{l}0.018^{\star *} \\
(0.009)\end{array}$ & $\begin{array}{c}0.084^{* * *} \\
(0.010)\end{array}$ & $\begin{array}{c}0.083^{\star * *} \\
(0.010)\end{array}$ \\
\hline lnfinanceasset & $\begin{array}{c}0.017^{* * *} \\
(0.002)\end{array}$ & $\begin{array}{c}0.095^{* * *} \\
(0.013)\end{array}$ & $\begin{array}{c}0.004 \\
(0.004)\end{array}$ & $\begin{array}{c}0.017^{* * *} \\
(0.002)\end{array}$ & $\begin{array}{c}0.016^{* * *} \\
(0.002)\end{array}$ \\
\hline Size & $\begin{array}{c}0.141^{* * *} \\
(0.013)\end{array}$ & $\begin{array}{c}0.108^{* * *} \\
(0.029)\end{array}$ & $\begin{array}{l}0.022^{* *} \\
(0.008)\end{array}$ & $\begin{array}{c}0.139^{* * *} \\
(0.013)\end{array}$ & $\begin{array}{c}0.140^{* * *} \\
(0.013)\end{array}$ \\
\hline Gender & $\begin{array}{l}-0.007 \\
(0.041)\end{array}$ & $\begin{array}{l}0.165^{* *} \\
(0.084)\end{array}$ & $\begin{array}{c}-0.109^{* * *} \\
(0.029)\end{array}$ & $\begin{array}{l}-0.003 \\
(0.040)\end{array}$ & $\begin{array}{l}-0.001 \\
(0.040)\end{array}$ \\
\hline Age & $\begin{array}{l}-0.005 \\
(0.006)\end{array}$ & $\begin{array}{l}-0.006 \\
(0.020)\end{array}$ & $\begin{array}{l}-0.006 \\
(0.007)\end{array}$ & $\begin{array}{l}-0.004 \\
(0.006)\end{array}$ & $\begin{array}{l}-0.004 \\
(0.006)\end{array}$ \\
\hline Edu & $\begin{array}{c}0.172^{* * *} \\
(0.009)\end{array}$ & $\begin{array}{c}0.106^{* * *} \\
(0.035)\end{array}$ & $\begin{array}{l}0.033^{* *} \\
(0.014)\end{array}$ & $\begin{array}{c}0.172^{* * *} \\
(0.009)\end{array}$ & $\begin{array}{c}0.171^{* * *} \\
(0.009)\end{array}$ \\
\hline Marriage & $\begin{array}{c}0.254^{* * *} \\
(0.056)\end{array}$ & $\begin{array}{c}0.154 \\
(0.205)\end{array}$ & $\begin{array}{c}0.028 \\
(0.066)\end{array}$ & $\begin{array}{c}0.252^{\star * *} \\
(0.056)\end{array}$ & $\begin{array}{c}0.254^{* * *} \\
(0.057)\end{array}$ \\
\hline Health & $\begin{array}{l}0.015^{\star *} \\
(0.007)\end{array}$ & $\begin{array}{c}0.132^{* * *} \\
(0.032)\end{array}$ & $\begin{array}{c}0.102^{* * *} \\
(0.010)\end{array}$ & $\begin{array}{c}0.012 \\
(0.007)\end{array}$ & $\begin{array}{c}0.010 \\
(0.007)\end{array}$ \\
\hline Work status & $\begin{array}{l}0.060^{*} \\
(0.035)\end{array}$ & $\begin{array}{c}0.107 \\
(0.127)\end{array}$ & $\begin{array}{c}0.135^{* * *} \\
(0.035)\end{array}$ & $\begin{array}{c}0.050 \\
(0.034)\end{array}$ & $\begin{array}{c}0.051 \\
(0.034)\end{array}$ \\
\hline Provincial fixed effect & YES & YES & YES & YES & YES \\
\hline Constant term & $\begin{array}{c}6.891^{* * *} \\
(0.185)\end{array}$ & $\begin{array}{c}2.899^{* * *} \\
(0.544)\end{array}$ & $\begin{array}{c}1.409^{* * *} \\
(0.142)\end{array}$ & $\begin{array}{c}6.795^{* * *} \\
(0.200)\end{array}$ & $\begin{array}{c}6.825^{* * *} \\
(0.196)\end{array}$ \\
\hline adj R-squared & 0.328 & 0.057 & 0.079 & 0.329 & 0.328 \\
\hline Sample size & 5314 & 5374 & 5374 & 5302 & 5302 \\
\hline
\end{tabular}

Note: The values in parentheses are robust standard errors. ${ }^{*}{ }^{* *},{ }^{* *}$ indicate significant levels at the $10 \%$, $5 \%$, and $1 \%$ significance levels, respectively, and () is the t-statistic value. 
From the regression results in the Table 6, we can see that social network has a positive impact on enjoyable consumption at the $1 \%$ significant level with an impact coefficient of 0.0716 , and has a positive impact on informal finance and social status of intermediary variables at the $10 \%$ significant level and $5 \%$ significant level, respectively. After introducing informal financial variables into model 1, informal finance has a positive impact on enjoyable consumption at the 5\% significant level. At this time, the impact of social network on enjoyable consumption is still significant at the $1 \%$ statistical level, and the coefficient is 0.0708 , which is smaller than model 1 . Therefore, informal finance has some intermediary effects in the process of social network influencing enjoyable consumption.

Similarly, after introducing social status variables, social status has a positive impact on enjoyable consumption at the $1 \%$ significant level. At this time, the impact of social network on enjoyable consumption is still significant at the $1 \%$ statistical level, and the coefficient is 0.0711 , which is smaller than model 1. Therefore, social status plays a part of intermediary effect in the process of social network influencing residents' consumption. In summary, the social network can promote the consumption-type consumption through the non-formal financial channels of relatives and friends, and the social and psychological factors for the pursuit of social status. The theoretical mechanism of the impact of social networks on household consumption summarized in the previous section has been verified.

\section{Robustness Test}

There are great differences in the degree of economic and financial development and household consumption concepts in the eastern, central and western regions of China. According to the provinces where households are located, this paper divides the samples into three regions: eastern, central and western regions, and studies the heterogeneity of the influence of social networks in different regions on consumption. Families with different income levels will have different quality and utility of social network, which will also have different impact on consumption. Therefore, this paper also divides the sample into high and low income families based on the average of the family's total annual income. Through empirical analysis of the impact of family social network on consumption in different regions and different levels of income, the robustness test is carried out.

From the regression results, we can see that in the eastern, central and western families, the impact of social network on consumption is significantly positive, and the impact on enjoyable consumption is more obvious, which is consistent with the previous empirical part of this paper. The impact of social network on consumption in the eastern region is weaker than that in the central and western regions. This is because the eastern region has a relatively high degree of marketization, mature financial system and less dependence on social relations than the families in the central and western regions, which makes the impact of the eastern family social network on consumption less significant than that of the central and western families (Table 7). 
Table 6. Regression results of families in eastern, central and western regions.

\begin{tabular}{|c|c|c|c|c|c|}
\hline & & $\begin{array}{c}\text { Total } \\
\text { consumption }\end{array}$ & $\begin{array}{c}\text { Survival } \\
\text { consumption }\end{array}$ & $\begin{array}{c}\text { Enjoyable } \\
\text { consumption }\end{array}$ & $\begin{array}{c}\text { Developmental } \\
\text { consumption }\end{array}$ \\
\hline \multirow{5}{*}{$\begin{array}{l}\text { Eastern } \\
\text { Region }\end{array}$} & Social network & $\begin{array}{c}0.037^{* * *} \\
(0.004)\end{array}$ & $\begin{array}{c}0.031^{* * *} \\
(0.004)\end{array}$ & $\begin{array}{c}0.055^{* * *} \\
(0.006)\end{array}$ & $\begin{array}{c}0.047^{* * *} \\
(0.008)\end{array}$ \\
\hline & Control variables & YES & YES & YES & YES \\
\hline & Constant term & $\begin{array}{c}9.217^{* * *} \\
(0.158)\end{array}$ & $\begin{array}{l}8.877^{* * *} \\
(0.157)\end{array}$ & $\begin{array}{c}6.548^{* * *} \\
(0.233)\end{array}$ & $\begin{array}{c}6.485^{* * *} \\
(0.287)\end{array}$ \\
\hline & adj R-squared & 0.258 & 0.235 & 0.310 & 0.159 \\
\hline & Sample size & 2741 & 2737 & 2737 & 2714 \\
\hline \multirow{5}{*}{$\begin{array}{l}\text { Central } \\
\text { region }\end{array}$} & Social network & $\begin{array}{c}0.076^{* * *} \\
(0.008)\end{array}$ & $\begin{array}{c}0.063^{* * *} \\
(0.008)\end{array}$ & $\begin{array}{c}0.122^{\star * *} \\
(0.013)\end{array}$ & $\begin{array}{c}0.060^{* * *} \\
(0.014)\end{array}$ \\
\hline & Control variables & YES & YES & YES & YES \\
\hline & Constant term & $\begin{array}{c}9.101^{\star * *} \\
(0.240)\end{array}$ & $\begin{array}{c}8.577^{\star * *} \\
(0.249)\end{array}$ & $\begin{array}{c}6.411^{\star * *} \\
(0.363)\end{array}$ & $\begin{array}{c}6.562^{\star * *} \\
(0.417)\end{array}$ \\
\hline & adj R-squared & 0.259 & 0.261 & 0.285 & 0.128 \\
\hline & Sample size & 1492 & 1486 & 1498 & 1481 \\
\hline \multirow{5}{*}{$\begin{array}{l}\text { Western } \\
\text { Region }\end{array}$} & Social network & $\begin{array}{l}0.054^{* * *} \\
(0.010)\end{array}$ & $\begin{array}{l}0.048^{* * *} \\
(0.010)\end{array}$ & $\begin{array}{c}0.088^{* * *} \\
(0.014)\end{array}$ & $\begin{array}{l}0.003^{* * *} \\
(0.017)\end{array}$ \\
\hline & Control variables & YES & YES & YES & YES \\
\hline & Constant term & $\begin{array}{c}8.799^{\star * *} \\
(0.275)\end{array}$ & $\begin{array}{c}8.172^{\star \star \star} \\
(0.280)\end{array}$ & $\begin{array}{c}6.076^{\star * *} \\
(0.372)\end{array}$ & $\begin{array}{c}6.177^{\star \star *} \\
(0.463)\end{array}$ \\
\hline & adj R-squared & 0.227 & 0.222 & 0.286 & 0.112 \\
\hline & Sample size & 1061 & 1054 & 1065 & 1046 \\
\hline
\end{tabular}

Note: The values in parentheses are robust standard errors. ${ }^{*}{ }^{* *},{ }^{* *}$ indicate significant levels at the $10 \%$, $5 \%$, and $1 \%$ significance levels, respectively, and () is the t-statistic value. Family and personal characteristic variables were controlled in the regression, and were omitted here due to space limitations.

Table 7. Regression results of families with different income levels.

\begin{tabular}{|c|c|c|c|c|c|}
\hline & & $\begin{array}{c}\text { Total } \\
\text { consumption }\end{array}$ & $\begin{array}{c}\text { Survival } \\
\text { consumption }\end{array}$ & $\begin{array}{c}\text { Enjoyable } \\
\text { consumption }\end{array}$ & $\begin{array}{c}\text { Developmental } \\
\text { consumption }\end{array}$ \\
\hline \multirow{5}{*}{$\begin{array}{l}\text { low-income } \\
\text { family }\end{array}$} & Social network & $\begin{array}{c}0.046^{* * *} \\
(0.005)\end{array}$ & $\begin{array}{c}0.039^{* * *} \\
(0.006)\end{array}$ & $\begin{array}{l}0.069^{* * *} \\
(0.008)\end{array}$ & $\begin{array}{c}0.037^{* * *} \\
(0.010)\end{array}$ \\
\hline & Control variables & YES & YES & YES & YES \\
\hline & Constant term & $\begin{array}{c}10.422^{* * *} \\
(0.199)\end{array}$ & $\begin{array}{c}10.125^{* * *} \\
(0.209)\end{array}$ & $\begin{array}{l}8.242^{* * *} \\
(0.271)\end{array}$ & $\begin{array}{l}7.016^{* * *} \\
(0.361)\end{array}$ \\
\hline & adj R-squared & 0.179 & 0.159 & 0.247 & 0.118 \\
\hline & Sample size & 1796 & 1790 & 1807 & 1786 \\
\hline \multirow{5}{*}{$\begin{array}{l}\text { High-income } \\
\text { family }\end{array}$} & Social network & $\begin{array}{l}0.018^{* * *} \\
(0.004)\end{array}$ & $\begin{array}{c}0.009^{* * *} \\
(0.004)\end{array}$ & $\begin{array}{l}0.043^{* * *} \\
(0.006)\end{array}$ & $\begin{array}{c}0.035^{* * *} \\
(0.008)\end{array}$ \\
\hline & Control variables & YES & YES & YES & YES \\
\hline & Constant term & $\begin{array}{l}4.272^{* * *} \\
(0.248)\end{array}$ & $\begin{array}{l}4.369^{* * *} \\
(0.252)\end{array}$ & $\begin{array}{l}-0.704^{*} \\
(0.403)\end{array}$ & $\begin{array}{l}3.235^{\star * *} \\
(0.518)\end{array}$ \\
\hline & adj R-squared & 0.258 & 0.215 & 0.284 & 0.129 \\
\hline & Sample size & 3502 & 3490 & 3495 & 3456 \\
\hline
\end{tabular}

Note: The values in parentheses are robust standard errors. ${ }^{*}{ }^{* *},{ }^{* *}$ indicate significant levels at the $10 \%$, $5 \%$, and $1 \%$ significance levels, respectively, and () is the t-statistic value. Family and personal characteristic variables were controlled in the regression, and were omitted here due to space limitations. 
It can be seen from the regression results that whether it is a high-income family or a low-income family, its social network has a significant role in promoting various types of consumption and has the greatest impact on enjoyment consumption. By comparing the influence coefficients of low-income and highincome families' social networks on consumption, we can see that the influence coefficients of low-income families are generally larger than those of high-income families at each level of consumption, which indicates that social networks are more conducive to stimulating the consumption of low-income groups and play a greater role in low-income groups. On the one hand, low-income families face more liquidity constraints and less ability to resist risks, so they rely more on social networks to obtain support and help. On the other hand, social networks are more likely to play a demonstration role in low-income families to stimulate the consumption of low-income families, while high-income families are more likely to obtain information and show their social status through social networks, so the role of social networks in promoting consumption can be more reflected in low-income families.

\section{Research Conclusions}

Supported by micro-household data, this paper examines the impact of family social network on residents' consumption level and consumption structure, solves the endogenous problem of social network by using instrumental variables, verifies the risk-sharing mechanism of social network, and further explores the impact of family social network in different regions and different levels of education on residents' consumption level and consumption structure. Through the empirical analysis, we get the following conclusions: 1) Family social network has a significant positive impact on residents' consumption level, among which the promotion of enjoyable consumption level is the most obvious. 2) On the one hand, social networks can provide financial support and informal financial channels for families to reduce uncertainty and risk sensitivity of family income, ease liquidity constraints and smooth consumption. On the other hand, it can also drive the consumption of residents through "demonstration effect" and "comparative effect", and affect the consumption level and consumption structure of residents. 3) Different types of families have different effects on consumption. Families in the central and western regions have more promotive effects on consumption than those in the eastern regions. Social networks are more conducive to stimulating the consumption of low-income groups, and play a greater role in low-income groups.

As a kind of social capital, social network can play an important role in providing social support to families and promoting consumption. Therefore, we should pay attention to cultivating and utilizing the social network of families, effectively exert the risk-sharing mechanism of family social network, so that social network can be transformed into effective social capital and forms an informal system to make up for the lack of formal system development. 


\section{Conflicts of Interest}

The author declares no conflicts of interest regarding the publication of this paper.

\section{References}

[1] Mitchell, J. (1969) The Concept and Use of Social Networks in Urban Situations. Manchester University Press, Manchester.

[2] Granovetter, M. (1973) The Strength of Weak Ties. American Journal of Sociology, 78, 1360-1380. https://doi.org/10.1086/225469

[3] Putnam, R. (1993) The Prosperous Community: Social Capital and Public Life. American Prospect, 13.

[4] Bloch, F., Genicot, G. and Ray, D. (2008) Informal Insurance in Social Networks. Journal of Economic Theory, 143, 36-58. https://doi.org/10.1016/j.jet.2008.01.008

[5] Zhang, S., Lu, M. and Zhang, Y. (2007) Is the Role of Social Capital Weakened or Strengthened with the Process of Marketization?-An Empirical Study from Rural Poverty in China. Economics (Quarterly), 2, 539-560.

[6] Lu, M. and Li, S. (2008) Social Capital, Informal System and Economic Development. Managing the World, 9, 161-165, 179.

[7] Li, T. and Guo, J. (2009) Risk Attitude and Stock Investment. Economic Research, 44, 56-67.

[8] Guo, Y.N., Zhang, J.H. and Huang, X.L. (2015) The Concept, Measurement and Impact of Social Networks: A Literature Review. Zhejiang Social Sciences, 2, 122-132, 160.

[9] Angelucci, M., De, G., Marcos, G., et al. (2010) Insurance and Investment within Family Networks. Working Papers, 580-596.

[10] Ma, X.Y. and Bai, Y.X. (2009) Income Risk Response Mechanism and Consumption Fluctuation of Chinese Farmers: Empirical Evidence from Shaanxi. Economics (Quarterly), 8, 1221-1238.

[11] Guo, Y.N., Yao, Y. and Foltz, J. (2012) Clan Network, Rural Finance and Smooth Consumption: Experience from 77 Villages in 11 Provinces. Rural China Observation, 1, 32-45.

[12] Hu, Y. and Wei, K.N. (2013) The Impact of Social Network on Urban and Rural Residents' Consumption Expenditure-Based on the Data of Social and Economic Change Survey in Western China. Urban Issues, 5, 16-20.

[13] Zhong, H. and Deng, L.Y. (2015) Risk Attitude, Social Network and Household Consumption. Consumer Economy, 31, 71-75.

[14] Wu, X.D. and Li, J.W. (2015) Social Networking, Liquidity Constraints and Household Consumption: Based on the Data of Chinese Household Microsurvey. Consumer Economy, 31, 22-27, 29.

[15] Hang, B. (2015) Human Expenditure and Urban Residents' Household Consumption: An Empirical Analysis Based on Status Seeking. Statistical Research, 32, 68-76.

[16] Nan, Y., Zhou, Q. and Huang, L. (2018) Social Network, Informal Finance and Farmers' Consumption Behavior: Empirical Evidence Based on Chinese Family Tracking Survey Data. Rural Economy, 6, 80-86.

[17] Yang, R., Chen, B. and Zhu, S. (2011) Research on the Demand Behavior of Farmers' Private Lending from the Perspective of Social Network. Economic Research, 46, 116-129. 
[18] Ma, G. and Yang, E. (2011) Social Network, Informal Finance and Entrepreneurship. Economic Research, 46, 83-94.

[19] Bian, Y. (2004) Sources and Functions of Urban Residents' Social Capital: Network Views and Surveys. Chinese Social Sciences, 3, 136-146, 208.

[20] Hu, F. and Chen, Y. (2012) Social Network and Farmer Lending Behavior: Evidence from China Family Dynamic Tracking Survey (CFPS). Financial Research, 12, 178-192.

[21] Chen, Z., Lu, M. and Sato, H. (2009) Who Has Entered the High-Income Industry? The Role of Relationship, Household Registration and Productivity. Economic Research, 44, 121-132.

[22] Lin, J., Wu, B. and Li, Z. (2016) Effective Social Network in Family Financing: Friendship Circle or Clan? Financial Research, 1, 130-144.

[23] Zhang, Y. and Lu, M. (2009) Can Social Networks Help to Raise the Wages of Migrant Workers? Managing the World, 3, 45-54.

[24] Staiger, D. and Stock, J.H. (1997) Instrumental Variables Regression with Weak Instruments. Econometrica, 65, 557-586. https://doi.org/10.2307/2171753

[25] Yi, X., Zhang, B., Yang, R. and Yang, B. (2012) Family Social Network and Farmer's Savings Behavior: An Empirical Study Based on Rural China. Managing the World, 5, 43-51, 187.

[26] Zhou, G. and Ma, G. (2015) Does Human Expenditure Squeeze out Normal Consumption? Evidence from Chinese Household Data. Zhejiang Social Science, 3, 15-26, 156.

[27] Wen, Z. and Ye, B. (2014) Mediation Effect Analysis: Methodological and Model Development. Progress in Psychological Science, 22, 731-745. 